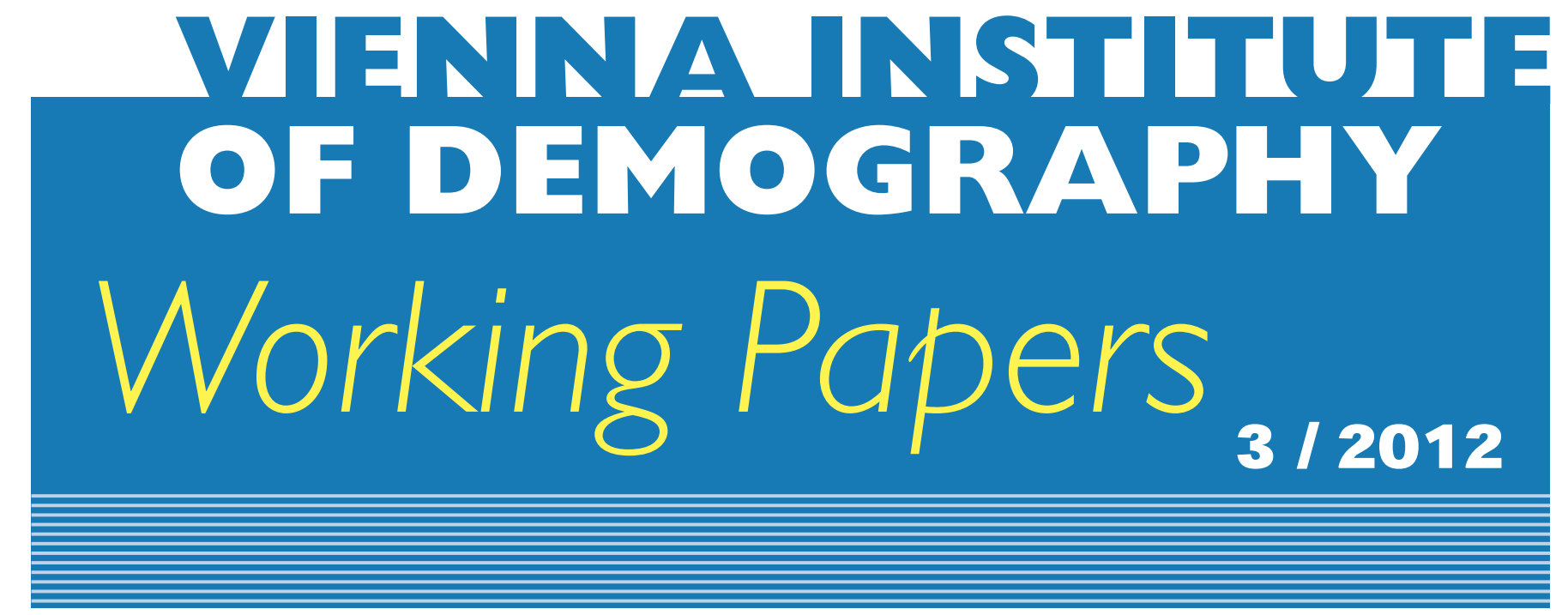

Anne Goujon, Éric Caron Malenfant, and Vegard Skirbekk

\title{
Towards a Catholic North America? Projections of Religion in Canada and the US Beyond the Mid-21st Century
}

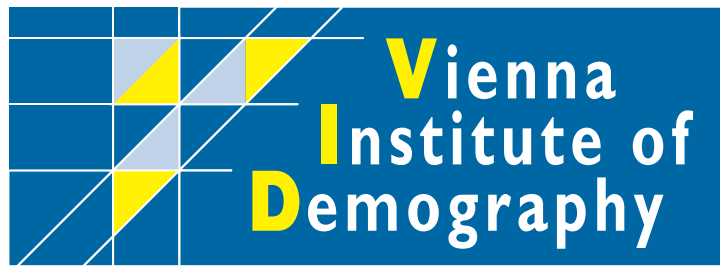

Vienna Institute of Demography Austrian Academy of Sciences

Wohllebengasse 12-14

A-I040Vienna $\cdot$ Austria

E-Mail:vid@oeaw.ac.at

Website: www.oeaw.ac.at/vid 


\begin{abstract}
Religion and religiosity are important identity markers, and changes in a country's religious composition may affect its culture, value orientations and policies. In recent decades the Protestants in both the US and Canada have lost their absolute population majority. In the present study we investigate the future of the religious composition in both the US and Canada jointly until the 2060s taking into consideration changes due to demographic forces, the level and composition of migration, fertility differentials and intergenerational religious transmissions. The joint focus on both the US and Canada allows one to better understand the commonalities and differences between these two nations which are tightly knit in terms of geography, politics, economics and culture. The projections reveal that North America should not become Catholic by mid-century but close to, with an increasing importance of minorities in the religious landscape.
\end{abstract}

\title{
Keywords
}

Religion, religious composition, transmission of religion, secularization, multistate projections.

\section{Authors}

Anne Goujon, senior researcher, Vienna Institute of Demography (Austrian Academy of Sciences), Wittgenstein Center for Demography and Global Human Capital (WIC) and at the International Institute for Applied Systems Analysis, WIC. Email: Anne.Goujon@oeaw.ac.at

Eric Caron Malenfant, senior analyst, Statistics Canada ${ }^{1}$. Email:

Eric.CaronMalenfant@statcan.gc.ca

Vegard Skirbekk, senior researcher, International Institute for Applied Systems Analysis, WIC. Email: skirbekk@,iiasa.ac.at

\section{Acknowledgements}

We would like to thank Laurent Martel and Patrice Dion for useful comments, Marcin Stonawski for his generous assistance with the data as well as participants in the VID colloquium on April 21 $1^{\text {st }}, 2011$ (Vienna, Austria) where preliminary results were presented for wise suggestions.

\footnotetext{
${ }^{1}$ The views and opinions expressed in this paper do not necessarily reflect those of Statistics Canada.
} 


\title{
Towards a Catholic North America? Projections of Religion in Canada and the US Beyond the mid-21 ${ }^{\text {st }}$ Century
}

\author{
Anne Goujon, Eric Caron Malenfant, and Vegard Skirbekk
}

\section{Introduction}

Religion and religiosity are important national identity markers, and changes in a country's religious composition and heterogeneity may affect its culture, value orientations or even policies, and support for social security and public transfers (Castells 2004, Guibernau 2007). The type of religion can affect population dynamics through, for instance, dominating religions' attempt to influence the regulation of partnerships and sexual relations. It may also affect how younger cohorts are socialized into a specific religious collectiveness influencing family formation attitudes and behavior (Goujon et al. 2007a, Lehrer 1996). Religious change could also be one cause of the US-Canada fertility reversal, where Canadian fertility was greater than US fertility until around 1970 (Boyle Torrey and Eberstadt 2007, Boyle Torrey 2008). Thereafter US fertility has consistently remained higher than Canadian fertility.

In recent decades the Protestants in both the US and Canada have lost their absolute population majority (Figures 1a and 1b). In the US the Protestant share is estimated to have decreased from above $60 \%$ in the 1980 s to around $47 \%$ by 2003 , although it remained the largest religious group. The US Catholic proportion reached a level of $28 \%$ in 2003, following growth among Hispanic-Catholics and decline among non-Hispanic Catholics (Skirbekk et al. 2010).

In Canada, Protestantism was the largest religion in every decennial census from 1891 to 1961. This 70-year period saw the Protestants share fall from 57\% to 49\% while the Catholic proportion rose from $42 \%$ to $47 \%$ (Statistics Canada 1993). Censuses from 1971 to 2001 have consistently shown that Catholicism is the largest religious entity in Canada, and in 2001 the Protestants were only $29 \%$ while the Catholics were $44 \%$ of the population (Canadian Census 2001).

In the present study we investigate the future of the religious composition in both the US and Canada jointly. Past projections that consider religion in either Canada or the US have been carried out (Bélanger and Caron Malenfant 2005, Caron Malenfant et al. 2010, Skirbekk et al. 2010). However, these projections have had a somewhat different focus (ethno-religious change for US, ethnocultural diversity change for Canada) and a too short projection horizons (2031 for Canada and 2043 for the US) to capture longer-term effects. Earlier projections also lacked explicit consideration of the impact of potential changes in interreligious union and their possible consequences the religious composition of the population. 
Figure 1a. Religious composition, Canada, 1971 to 2001



Source: Census data, various years

Figure 1b. Religious composition, United States, 1972 to 2006

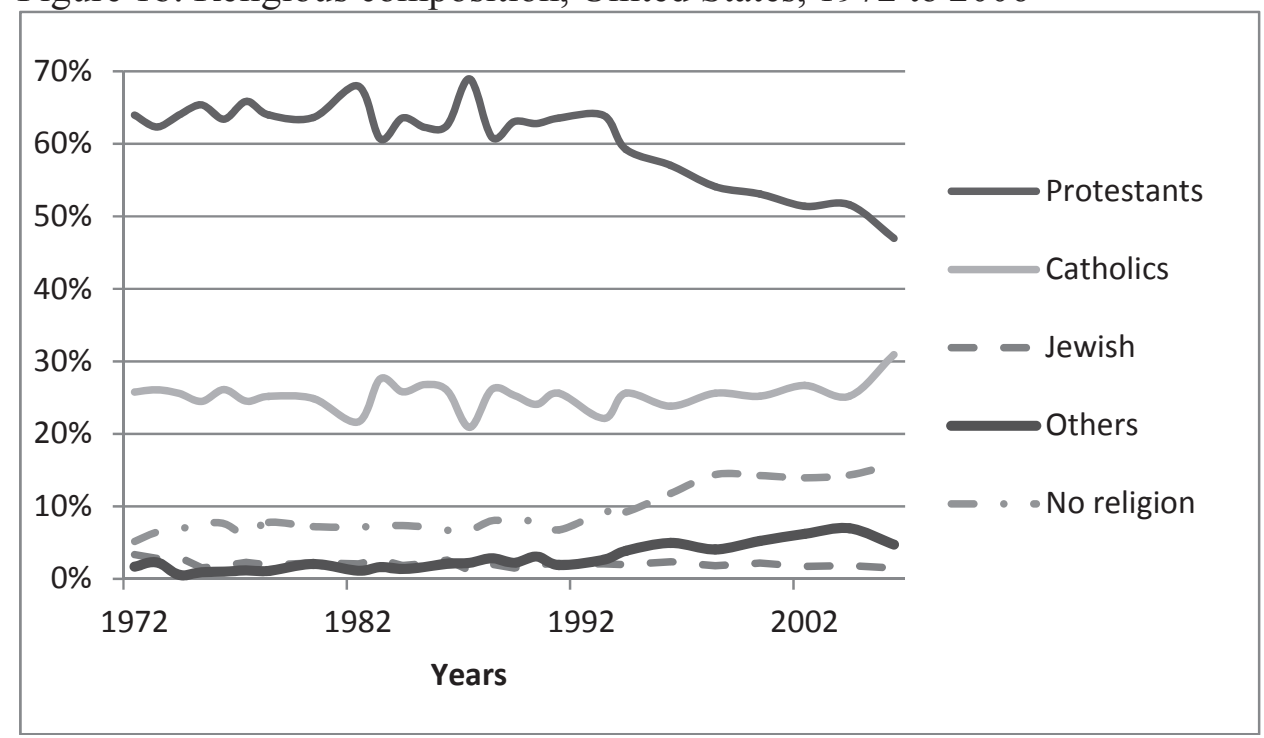

Source: US GSS, various years

We take these issues into account, use religious categories that are comparable across the two countries, and extend the time horizon to the 2060s. The longer projection period allows us to better understand how religion changes due to demographic forces, the level and composition of migration, fertility differentials, conversions and intergenerational religious transmissions, in addition to population inertia. 
The joint focus on both the US and Canada allows one to better understand the commonalities and differences between these two nations which are tightly knit in terms of geography, politics, economics and culture. We also include what the case would be if the US would have Canadian parameters and vice versa to get a better understanding of the different driving forces behind the changes occurring in both countries in terms of religious composition of their population.

This study takes advantage of the richness of the Canadian long-form 2001 Census, which completion was compulsory to the population and covered $20 \%$ of all households, as well as the Ethnic Diversity Survey of 2002 (sample size of the EDS is N=42476), which allows us to parameterize the conversion rates. For the United States, we use pooled data from the General Social Survey from 2000 to 2006 (sample size of the GSS 2000-2006 is N=12674).

\section{Drivers of Religious Change}

The change in the number of persons in the different religious affiliations through conversion is important, and the most common "switch" is from various religions to the "no religion" group. In the US, more than one in five adults has a different religion than what they had in childhood. In Canada, similarly, about one in five persons declared a different religious denomination than that of their mother when they were aged less than 15 years old, according to the EDS. The substantial conversion rates are in line with findings from other Catholic and Protestant dominated countries which have large conversion rates (Goujon et al. 2007a, Lehrer 1996, 2004).

Fertility and migration patterns have different effects on the religious demography of Canada and the US. In the US, the Catholic share increases due to fertility differentials, as the overall TFR in 2003 was estimated to be 2.1 children per woman for Protestants, while for Catholics it was 2.3 children per woman (Skirbekk et al. 2010). In Canada, however, these demographic forces have the opposite effect, where in 2001 fertility differentials benefit Protestants: Catholics had a TFR of 1.5 children per woman, while Protestants had a higher TFR with 1.7 children per woman.

Catholics increase their proportion through immigration to the US, as the share of Catholics among migrants is about $45 \%$ in $2003-2006$, while it is only $28 \%$ in 2003 among the US resident population. In Canada, however, immigration reduces the Catholic proportion, since among recent migrants (admitted between 1996 and 2001) only 20\% were Catholic (while $44 \%$ of the total population in Canada were Catholics in 2001). Also, in both countries, the share of Protestants among the migrants (10\% in Canada and $8 \%$ in the US) is far lower than their share in the overall population, thus contributing to decrease in the share of this denomination.

The current composition of immigration leads to an increase in the share of religious minorities (Muslims, Other religions, Hindus and Buddhists) for both countries, a decrease in 
the share of the Jewish population in the US and no effect on the share of the Jewish population in Canada. Muslims and Hindus ${ }^{2}$ also gain through a higher fertility.

The share without a religious affiliation is also affected in different ways by migration in the two countries. It rises due to immigration in Canada ( $23 \%$ of the immigrants are not affiliated compared to $17 \%$ of the resident population), while this group is negatively affected by immigration in the US where the share without affiliation is less in the immigrant population than in the native population, $8 \%$ versus $17 \%$. Their low fertility has a depressing effect on the population share in both countries: the TFR of the unaffiliated is 1.7 children in the US (as opposed to an overall TFR of 2.08) and 1.4 children in Canada (as opposed to an overall TFR of 1.54).

\section{Projection Methodology}

In order to project the population of Canada and the US by religion, we estimate the initial population by age, sex and religious denomination. We also estimate age- and religion-specific fertility rates, age-, sex- and religion-specific net-migration numbers. In addition, we focus on the impact of mixed unions and religious conversion rates by age and sex. We employ both expected and alternate scenarios based on varying fertility, conversion and net-migration assumptions. The projections are conducted using the PDE population projection software, a tool developed at IIASA ${ }^{3}$ and used for multistate population projections - in case of several states that interact with each other.

\subsection{Base Population}

The US estimates rely on General Social Survey (GSS) data and we choose 2003 as a starting year, due to its proximity to the 2001 Canadian census and pool GSS survey waves (20002006) together in order to increase sample size for the base population ( $\mathrm{N}=12674)$. As well data on minority religions are available only from 2000. To ensure that the GSS data are fairly representative we compared its findings to alternative surveys that have been conducted since the year 2000 (from Baylor, ARIS and PEW) and found that although the estimates differ, the various surveys present a broadly consistent picture, with about half the population Protestant, a quarter Catholic, and about one in eight without religion, with a scattering of smaller groups (Jewish, Hindu, Muslim, and other religious groups) ${ }^{4}$.

For Canada, the base population consists of the 2001 long-form census ${ }^{5}$ of the population (20\% sample or about six million persons), adjusted for census net under-coverage. Our base

\footnotetext{
${ }^{2}$ This is not the case of Buddhists whose fertility is actually lower than the average Canadian fertility.

${ }^{3}$ It can be downloaded from this link www.iiasa.ac.at/Research/POP/pub/software/pde/pdesetup.zip

${ }^{4}$ See Skirbekk et al. (2010) for more details.

${ }^{5}$ The 2001 Census is to date the most recent and comprehensive dataset on religious affiliation in Canada as the 2006 Canadian census did not include a question on religious denomination.
} 
population excludes institutional population since the long-form containing the question on religious denomination was not distributed to institutions.

For the base population, we use the following seven religious categories for both countries: Protestant, Catholic, Muslim, Hindu and Buddhist, Jewish, other religions, and no religion. Figure 2 and Figure 3 show the religious distribution of both starting population.

Figure 2. Population distribution by age and religious denomination, Canada, 2001

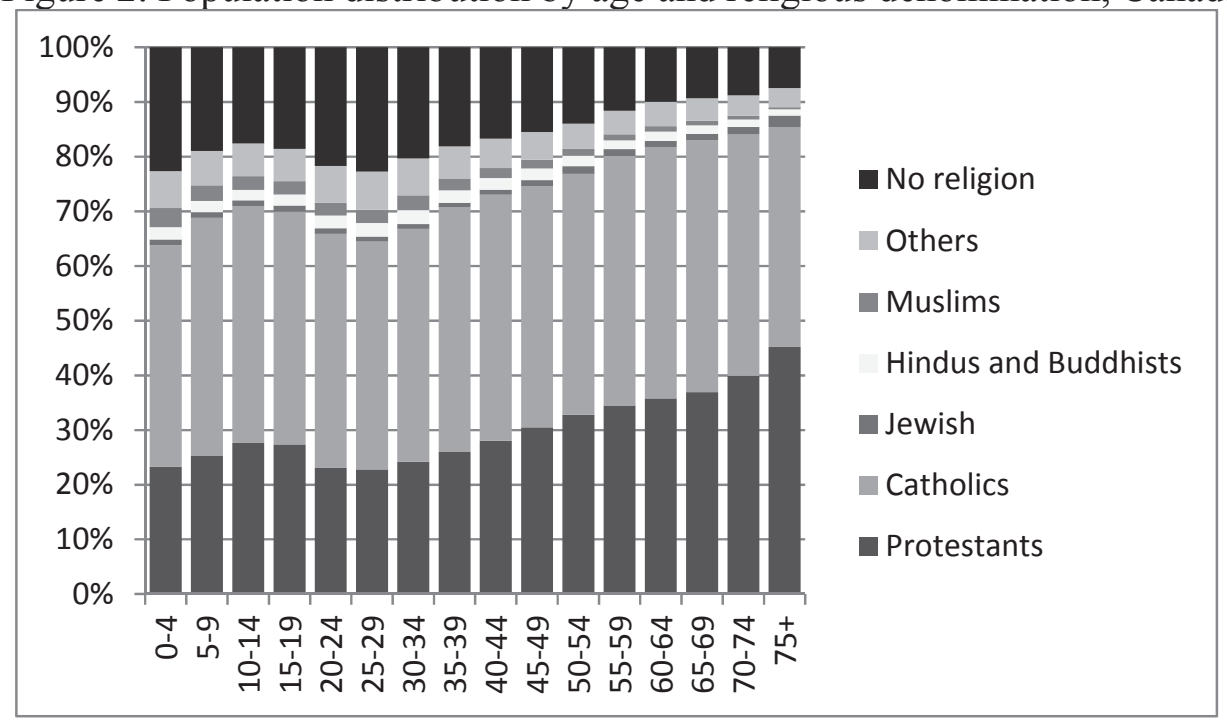

Source: Census (2001) adjusted

Figure 3. Population distribution by age and religious denomination, United States, 2003



Source: GSS 2003-2006 adjusted 


\subsection{Base-Year Mortality}

For mortality for the United States, we assume a single value for each age group and sex following the estimates of the National Center for Health Statistics (NCHS), available for the base year in Kung et al. (2008) and the long-range projections for life expectancy of the census bureau available in Hollmann et al. (2000). For Canada we follow Statistics Canada's estimates and projections by age and sex developed in their most recent population projections (Statistics Canada, 2010).

The evidence of a relationship between religion and mortality is inconclusive, and while some studies find religiosity to be associated with better health outcomes (for a review, see Hummer et al. 2004), on the other hand, the more religious tend to have lower education levels (Glaeser and Sacerdote 2008, Inglehart and Baker 2000) which could suggest they would have worse health outcomes (Groot and Van Den Brink 2007). Lerch et al. (2010) show that in the case of Switzerland, one of the few countries where religion is registered at the time of death as well as in the census, differentials in survival ratio by religion tend to be less important than other factors affecting mortality such as sex, education, and marital status.

\subsection{Base-Year Net-Migration}

Immigration forms a crucial part of the projection and is the most important growth factor for several religious groups. In our model we include annual net international migration by religion, age and sex.

Annual US net-migration figures come from the Population Estimates Program of the US Census Bureau International Database (2010) and from their official projections, and for Canada from the Population estimates program of Statistics Canada as well as their official population projections (Statistics Canada, 2010). The data for Canada refers to migration inand out-flows whereas the US data is already aggregated to net-migration.

There are two major difficulties in estimating immigration differentials by religion, especially for the US. One is inherent to the immigration process in the United States where illegal flows from across the Mexican border, which we, as in official US population projections, have included (Hollman et al. 2000) but possibly underestimated (Passel 2006), play an important role -illegal immigration being assumed much lower in Canada. However, a substantial share of legal immigration consists of formerly undocumented immigrants who have been granted amnesty, while many other undocumented migrants will return to their country of origin. The second difficulty has to do with the lack of data on the religion of the immigrants in the US, which lead us to use the "random migrant" assumption in terms of migration. We retrieve the number of persons obtaining legal permanent resident status by religion between 2003 and 2007 (U.S. Department of Homeland Security 2009) and based their religion on the shares of population by religion in their home country using the best estimates from the World Religion Database (WRD), assuming that immigrants are randomly selected in terms of religion in their country of origin. For the US, The New Immigrant Survey (NIS) (e.g. Jasso and Rosenzweig 2006) produce fairly similar proportions of most religious groups and sensitivity analysis 
shows that using NIS estimates would not affect the main results of our projections (Skirbekk et al. 2010). The net numbers of migrants were further distributed by age and sex using the shares used in the 2009 national population projections, in the constant net international migration scenario ${ }^{6}$ which do not change over the projection period (2010-2050).

For Canada we retrieved from the 2001 Census the religious distribution of migrants who arrived between 1996 and 2001, by country of birth, and applied the resulting distribution to the migrants who moved to Canada between 2001 and 2006 by country of birth (according to the 2006 census). The total numbers of immigrants by religion were then distributed by age and sex, according to both the census and the Population estimates program of Statistics Canada (2001 to 2006). Emigrants by age, sex and religion were subtracted from the corresponding immigration figures to obtain the net international migrations religious composition assumption. In the absence of data on religious denomination of emigrants from Canada, they were assumed to be selected randomly among the religious groups.

The resulting distributions of net migrants for both countries are shown in Figure 4 and Figure 5. The main differences between United States and Canada in terms of religious denomination of their migrants are related to the shares of Catholics, Hindu-Buddhists and those with no religion. While Catholicism is the most common denomination of migrants to the US with $42 \%$, it represents only $18 \%$ of the migrants in Canada, where the shares of non affiliated $(21 \%)$ and Hindu-Buddhist $(22 \%)$ are more important, thus reflecting differences in the origins of migrants in the two countries: more immigrants of Latin American origins in the case of US, more from Chinese and South Asian origins for Canada. On the other hand, the share of Protestant, Muslim, Jewish and other religion populations are very similar across both countries.

Figure 4. Religious distribution of net-migration in 2001, Canada

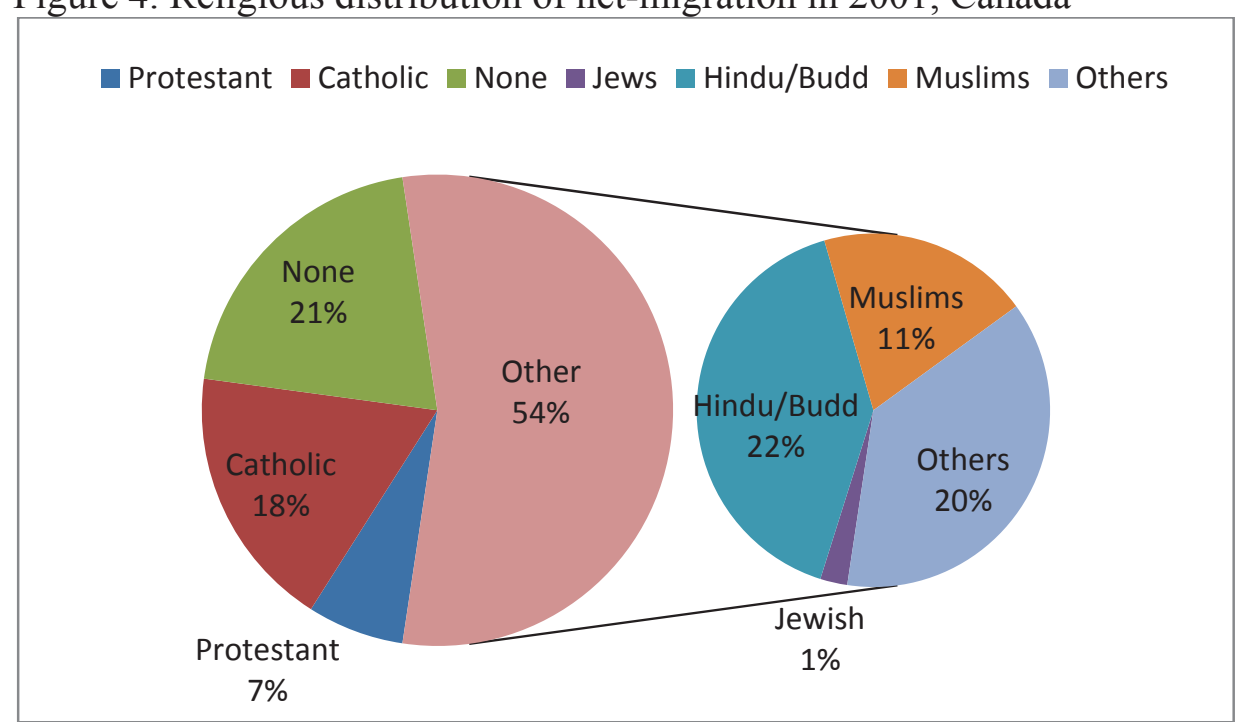

Source: Authors' calculations based on several sources (see above)

${ }^{6}$ See US Census Bureau www.census.gov/population/www/projections/2009projections.html [16/6/2011] 
Figure 5. Religious distribution of net-migration in 2003, United States



Source: Authors' calculations based on several sources (see above)

\subsection{Base-Year Fertility}

Fertility data for both the US and Canada is given in Table 1. Fertility differences by religion in the USA were estimated from GSS data on children ever born to women aged 40 to $59^{7}$ for the period 2000-2006, and the differentials were then proportionally adjusted and applied to the TFR reported for 2003-2007 by the US Census Bureau. For Canada, the age-specific fertility rates by religious group could be derived from census data, by applying to this database the own-children method to estimate fertility ${ }^{8}$. The age-specific fertility rates by religion were adjusted so that the rates for Canada overall be the same as those obtained by Vital Statistics in 2001 to 2007 and the same as the assumed rates (central assumption of the most recent Statistics Canada's official projections) for the following years.

In the US, Catholics had a significantly higher fertility than Protestants early in the $20^{\text {th }}$ century, but this waned in the second half of the 20th century (Jones and Westoff 1979, Sander 1992). However, the large influx of Hispanic Catholics with higher fertility has lead to a rise in the relative fertility of the Catholics in recent years and again divergence between Protestant and Catholic fertility rates.

In Canada, Catholics used to have larger families than Protestants, but the gap decreased over the $20^{\text {th }}$ century (Krotki and Lapierre 1968). This relation has reversed in recent years

\footnotetext{
${ }^{7}$ For Muslims, we based the differential on the 35 to 59 population to increase sample size.

${ }^{8}$ For more details on the method, please consult Grabill and Cho (1965), as well as Bélanger and Gilbert (2003) or Caron Malenfant and Bélanger (2006) for examples of application to Canadian data.
} 
implying that today Protestants have relatively larger families. A Canadian study revealed that socio-economic characteristics can explain this difference between Catholics and Protestants, but not the lower fertility of the non affiliated nor the higher fertility of the Muslim and Jewish denominations, thus suggesting that religion is likely to have an independent effect (Caron Malenfant and Bélanger 2006). The low fertility among those with no religion is in line with many other studies showing that low religiosity corresponds with low levels of fertility (Goujon et al. 2007b, McQuillan 2004).

Table 1. Estimated period total-fertility and differentials in 2001-2005 (Canada) and 20032007 (United States)

\begin{tabular}{|l|c|c|}
\hline Religion: & $\begin{array}{c}\text { Canada (2001- } \\
2005)\end{array}$ & $\begin{array}{c}\text { United States } \\
(2003-2007)\end{array}$ \\
\hline Protestant & 1.63 & 2.12 \\
\hline Catholic & 1.49 & 2.38 \\
\hline Jewish & 1.83 & 1.43 \\
\hline Hindu-Buddhist & 1.66 & 1.73 \\
\hline Muslim & 2.35 & 2.84 \\
\hline Other religion & 1.68 & 1.64 \\
\hline No religion & 1.39 & 1.66 \\
\hline Total & 1.54 & 2.08 \\
\hline
\end{tabular}

Source: Authors' calculation based on GSS and US census Bureau for the US and on 2001 Census for Canada

\subsection{Conversion, Intermarriage and Parent-Child Religious Transmissions}

Growing intensity of interreligious union are important as it can affect the fertility levels of couples and the choice of a religious denomination for their children. Several religious communities oppose intermarriage, and perceive it as a threat mostly because of the low rates of transmission of religion to one's children. For instance, high intermarriage levels lead to worries in the US Jewish community that their religious group may eventually disappear (Bisin et al. 2004, Sherkat 2004). However, for the US Bisin et al. (2004) suggest that intermarriage rates will be curbed by strong preferences for intergenerational transmissions of religions to their children and substantial population shares that have a low tolerance for marrying across religious lines. Kalmijn and van Tubergen (2009) look at intermarriage patterns in the US (based on CPS data) and find religious dissimilarity between nationality groups significantly negatively influence intermarriage levels.

Clark (2008) studies trends in interreligious unions (marriages and common-law unions) in Canada and shows that the total share of interreligious unions (using 12 religious groups) has risen from $15 \%$ in 1981 to $19 \%$ in 2001. Among Catholics and Protestants, the level of interreligious unions had by 2001 risen to $16 \%$ and $21 \%$, respectively. Among the Jewish people, the interreligious share almost doubled between 1981 and 2001 , from $9 \%$ to $17 \%$. Among Hindus and Muslims, however, the interreligious share decreased slightly from 13\% and $11 \%$ to $9 \%$ for both groups (which may be related to a high share immigrating in recent 
years combined with a low level of intermarriage among new migrants). It could also be related to a higher degree of religiosity in these groups, which is related to lower levels of intermarriage (Bibby 2002, Sherkat 2004).

In the US, the 1991 and 1998 GSS survey waves included a question on respondent's religion and the religion of the mother and father $(\mathrm{N}=2289$ non missing answers). These data suggest that among those with two Catholic parents, $77 \%$ kept their parents religion, while $89 \%$ of those with Protestant parents kept their parents' religion. Mothers are more influential in the transmission of religion and if the mother is Catholic and the father is Protestant, $43 \%$ become Catholic and 36\% Protestant. If the mother is Protestant and the father Catholic, 59\% become Protestant and $16 \%$ Catholic.

In Canada, EDS data on the respondent's religion and that of his/her parents when the respondent was less than 15 also show high retention rates when both parents share a religion, but higher for Catholics (91\%) than for Protestants (82\%). In case of mixed unions between a Catholic and a Protestant, the mother is more influential if she is Catholic, with $52 \%$ of the children being Catholic and 30\% Protestant. If the mother is Protestant, the percentage that becomes Catholic and Protestant is not significantly different, at about $40 \%$. For children born to couples where one parent has a religious affiliation and the other one belongs to the group "without religion", the religious transmission is far weaker. Nevertheless, if one parent has a religious affiliation, he/she tends to have a stronger influence on the child affiliation than the secular person, and more so if the woman is religious rather than the father (Bovay and Broquet 2004). The Canadian data shows that, in case of children born in interreligious unions between a parent with a religious denomination and another without, the share who had no religion at a later stage is about $50 \%$ if the mother is the parent without religion and about $40 \%$ if the non religious parent is the father.

In our model, our conversion matrix includes some of the effect of inter-religious unions through conversion trends (some convert for marriage reasons, moreover parental interreligious unions patterns can affect the degree and the direction of own religious switching). The Canadian data results from a comparison between the religion of the respondent and the religion of the respondent's mother when the respondent was aged less than 15 years old. Therefore, it estimates both intergenerational and intragenerational changes. In the US, the data used so far compares the religion of the respondent at two points in time: the day of the interview and during childhood ${ }^{9}$. Thus, it only estimates intragenerational changes. Given that the religious mobility is higher among the population whose parents were in a mixed union and that the proportion of mixed unions is likely to increase in the future, we decided to establish a scenario that assumes an increasing religious mobility. To do so, we computed the probability to change religion separately for respondents whose parents were in a mixed union and for those having parents with the same religion. Those probabilities are used to create new matrices in which the weight of the patterns for persons with parents in a mixed union is double than in the baseline matrices.

\footnotetext{
${ }^{9}$ The exact question in the GSS is "In what religion were you raised?"
} 
The estimates for both countries concern net religious mobility (as shown in Table 2), and were computed by sex. The data in Canada allowed for sex specific mobility rates. In the US, the sex differentials were based on the gender difference in retention across all religions, showing that men were 6 percent more likely to switch out of their own religion than women (Skirbekk et al. 2010). We assume that changes tend to be concentrated among the 20-24 year old, which is based on evidence from a number of countries that these are the years when religious conversions/secularization is most likely to occur (Crockett and Voas 2006; Hoge 1981, Iannaccone 1992).

Table 2. Estimates of religious mobility in Canada ${ }^{10}$

\begin{tabular}{|l|r|r|r|r|r|r|r|}
\hline To: & Protestant & Catholic & \multicolumn{1}{l|}{$\begin{array}{l}\text { Hindu- } \\
\text { Buddhist }\end{array}$} & \multicolumn{1}{l|}{ Jewish } & Muslim & Other & \multicolumn{2}{l|}{$\begin{array}{l}\text { No } \\
\text { religion }\end{array}$} \\
\hline Protestant & $76 \%$ & $6 \%$ & $0 \%$ & $0 \%$ & $0 \%$ & $3 \%$ & $15 \%$ \\
\hline Catholic & $4 \%$ & $86 \%$ & $0 \%$ & $0 \%$ & $0 \%$ & $2 \%$ & $7 \%$ \\
\hline Hindu-Buddhist & $6 \%$ & $8 \%$ & $59 \%$ & $0 \%$ & $0 \%$ & $6 \%$ & $22 \%$ \\
\hline Jewish & $0 \%$ & $0 \%$ & $0 \%$ & $90 \%$ & $0 \%$ & $0 \%$ & $10 \%$ \\
\hline Muslim & $0 \%$ & $0 \%$ & $0 \%$ & $0 \%$ & $93 \%$ & $0 \%$ & $7 \%$ \\
\hline Other & $7 \%$ & $4 \%$ & $0 \%$ & $0 \%$ & $0 \%$ & $77 \%$ & $12 \%$ \\
\hline No religion & $11 \%$ & $7 \%$ & $1 \%$ & $0 \%$ & $0 \%$ & $5 \%$ & $75 \%$ \\
\hline
\end{tabular}

Source: EDS (2002)

Table 3. Estimates of religious mobility in the US

\begin{tabular}{|l|r|r|r|r|r|r|r|}
\hline To: & Protestant & Catholic & \multicolumn{1}{l|}{$\begin{array}{l}\text { Hindu- } \\
\text { Buddhist }\end{array}$} & \multicolumn{1}{l|}{ Jewish } & Muslim & Other & $\begin{array}{l}\text { No } \\
\text { religion }\end{array}$ \\
\hline Protestant & $81 \%$ & $3 \%$ & $0 \%$ & $0 \%$ & $0 \%$ & $3 \%$ & $12 \%$ \\
\hline Catholic & $11 \%$ & $75 \%$ & $0 \%$ & $0 \%$ & $0 \%$ & $4 \%$ & $10 \%$ \\
\hline Hindu-Buddhist & $12 \%$ & $6 \%$ & $55 \%$ & $1 \%$ & $2 \%$ & $3 \%$ & $20 \%$ \\
\hline Jewish & $3 \%$ & $1 \%$ & $1 \%$ & $81 \%$ & $0 \%$ & $1 \%$ & $14 \%$ \\
\hline Muslim & $3 \%$ & $0 \%$ & $5 \%$ & $0 \%$ & $71 \%$ & $7 \%$ & $13 \%$ \\
\hline Other & $29 \%$ & $4 \%$ & $1 \%$ & $0 \%$ & $0 \%$ & $47 \%$ & $19 \%$ \\
\hline No religion & $32 \%$ & $6 \%$ & $1 \%$ & $2 \%$ & $0 \%$ & $4 \%$ & $56 \%$ \\
\hline
\end{tabular}

Source: Based on GSS (2000-2006)

\footnotetext{
${ }^{10}$ In this table, cells with a coefficient of variation higher than $33.3 \%$ or with sample sizes of 10 or less were suppressed. The table still includes cells with high coefficient of variations, to be interpreted with caution (cells with numbers less that $2 \%$ and cells from Jewish to no religion and from Muslim to non religion have coefficients of variations higher that $16.6 \%$ ).
} 


\subsection{Scenarios}

We develop a set of different scenarios consistent but overall specific to the two countries where we look at the impact of different migration levels, fertility differentials and whether conversion trends continue or not. Each scenario differs from the "recent situation" scenario by only one component, in order to assess the sensitivity of results to each of them. The scenarios are presented in Table 4. By the sheer difference in population size of Canada and the United States, it is clear that the results are strongly influenced by the United States whose population is almost ten times larger than the Canadian population (318 million vs. 34 million). That is why we included some contra-factual simulations of US and Canadian demographic variables on religious mobility and migration composition.

Table 4. Scenario Matrix

\begin{tabular}{|c|c|c|c|c|c|c|}
\hline \multirow[b]{2}{*}{ Fertility } & \multirow[b]{2}{*}{$\begin{array}{l}\text { Religious } \\
\text { mobility }\end{array}$} & \multicolumn{5}{|c|}{ Net-migration } \\
\hline & & $\begin{array}{l}\text { Recent } \\
\text { situation }\end{array}$ & $\begin{array}{c}\text { Canadian } \\
\text { net-migration } \\
\text { composition }\end{array}$ & $\begin{array}{c}\text { American } \\
\text { net-migration } \\
\text { composition }\end{array}$ & $\begin{array}{l}\text { No net- } \\
\text { migration }\end{array}$ & $\begin{array}{l}\text { Double the } \\
\text { net- } \\
\text { migration }\end{array}$ \\
\hline \multirow{5}{*}{$\begin{array}{l}\text { Recent } \\
\text { situation }\end{array}$} & $\begin{array}{l}\text { Recent } \\
\text { situation }\end{array}$ & $\begin{array}{c}\text { H0 } \\
\text { Recent } \\
\text { situation }\end{array}$ & $\begin{array}{l}\text { H1 Canadian } \\
\text { net-migration } \\
\text { composition }\end{array}$ & $\begin{array}{l}\text { H2 American } \\
\text { net-migration } \\
\text { composition }\end{array}$ & $\begin{array}{c}\text { H3 } \\
\text { No net- } \\
\text { migration }\end{array}$ & $\begin{array}{c}\text { H4 } \\
\text { Double the } \\
\text { net- } \\
\text { migration }\end{array}$ \\
\hline & $\begin{array}{l}\text { Canadian } \\
\text { religious } \\
\text { mobility }\end{array}$ & $\begin{array}{l}\text { H5 } \\
\text { Canadian } \\
\text { religious } \\
\text { mobility }\end{array}$ & & & & \\
\hline & $\begin{array}{l}\text { American } \\
\text { religious } \\
\text { mobility }\end{array}$ & $\begin{array}{l}\text { H6 } \\
\text { American } \\
\text { religious } \\
\text { mobility }\end{array}$ & & & & \\
\hline & $\begin{array}{l}\text { No } \\
\text { religious } \\
\text { mobility }\end{array}$ & $\begin{array}{c}\mathbf{H 7} \\
\text { No religious } \\
\text { mobility }\end{array}$ & & & & \\
\hline & $\begin{array}{l}\text { Mixed } \\
\text { unions }\end{array}$ & $\begin{array}{c}\text { H8 } \\
\text { Mixed } \\
\text { Unions }\end{array}$ & & & & \\
\hline $\begin{array}{c}\text { Early } \\
\text { convergence }\end{array}$ & $\begin{array}{l}\text { Recent } \\
\text { situation }\end{array}$ & $\begin{array}{c}\text { H9 } \\
\text { Early fertility } \\
\text { convergence }\end{array}$ & & & & \\
\hline $\begin{array}{c}\text { Late } \\
\text { convergence }\end{array}$ & $\begin{array}{l}\text { Recent } \\
\text { situation }\end{array}$ & $\begin{array}{l}\text { H10 } \\
\text { Late fertility } \\
\text { convergence }\end{array}$ & & & & \\
\hline
\end{tabular}


The scenarios envisaged are the following:

\section{Fertility:}

1- Recent situation: Fertility differentials by religious denomination remain constant at levels shown in Table $1^{11}$. The overall fertility will change through changes to the different weights of the several religious groups in the total population. In Canada, the TFR will reach 1.81 by the end of the projection period and 2.10 in the US - compared to 1.54 and 2.08 in the starting period.

2- Early convergence: The differentials existing in the fertility of women by religious denomination disappear by 2013-17 in the US and by 2011-15 in Canada to reach 2.1 in the US and 1.7 in Canada and stay at that level until the end of the projection period.

3- Late Convergence: The fertility differentials remain constant as in the recent situation scenario and only disappear in 2033-37 in the US and in 2031-35 in Canada.

\section{Religious mobility:}

1- Recent situation: The transition rates between the seven religious groups shown in Table 2 and Table 3 are kept constant until the end of the projection period.

2- Canadian religious mobility: The matrices of religious mobility shown in Table 2 and Table 3 are exchanged so that the religious mobility of Canada is applied to the US.

3- American religious mobility: The matrices of religious mobility shown in Table 2 and Table 3 are exchanged so that the religious mobility of the US is applied to Canada.

4- No religious mobility: We assume that from 2001 for Canada and 2003 for the US, everybody stays in the religion they are born, inherited from their mother.

5- Mixed unions: Conversion rates are increased by reweighting the religious mobility matrices to double the importance of conversion rates of children from mixed unions, based on the Canadian case. For the US, the increase in religious mobility estimated for Canada is applied to the US matrices.

\section{Net- migration:}

1- Recent situation: The total migration follows the projections of the respective statistical agencies. In the US, it means that the net-migration is increasing from 874 thousand in 2003 to 2055 thousand in 2050, and further to 2300 thousand in 2063, following the increase observed in the last period. In Canada, following population estimates and numbers obtained from the central assumption of the official Statistics Canada's projections (Statistics Canada 2010, scenario M1), it would increase from 215 thousand in 2001 to 347 thousand in 2061. The composition of immigration presented in Figure 4 and 5 is kept constant until the end of the projection.

\footnotetext{
${ }^{11}$ More precisely, and as mentioned previously, for Canada the rates presented in Table 1 are adjusted to meet by 2011-2015 the official central assumption of Statistics Canada (1.7 children per woman at the national level) and are maintained constant after. The adjustment does not affect the differentials.
} 
2- Canadian net-migration composition: We apply the religious composition of Canada net-migration by country of birth (based on the 2001 census) to the US composition.

3- American net-migration composition: We apply the religious composition of the US net-migration by country of birth (based on the WRD database) to the Canadian composition.

4- No net-migration: We assume that from 2011 in Canada and 2013 in the US, netmigration would be zero.

5- Double the net-migration: We assume that from 2011 in Canada and 2013 in the US, net-migration would double the value of the recent situation migration variant.

\section{Results $^{12}$}

The results are first analyzed at the level of North America. Our business as usual scenario recent situation - shows that North America would not be Roman Catholic by the middle of the century but it would be close at the end of the projection period in 2062 where the Catholics would make up to $32 \%$ of the population, compared to $34 \%$ for the Protestants (Figure 6). However most of the changes in the relative share of the Catholics and Protestants in North America is due to the decline in the share of the Protestant population rather than in the increase of the share of the Catholic population which remains quite stable: from $30 \%$ in 2002 to $32 \%$ in 2062 whereas the share of Protestants decreases dramatically from $45 \%$ to $34 \%$ during the same period of time.

Figure 6. Share by religious category, Scenario 'Recent situation', North America, 2002-2062

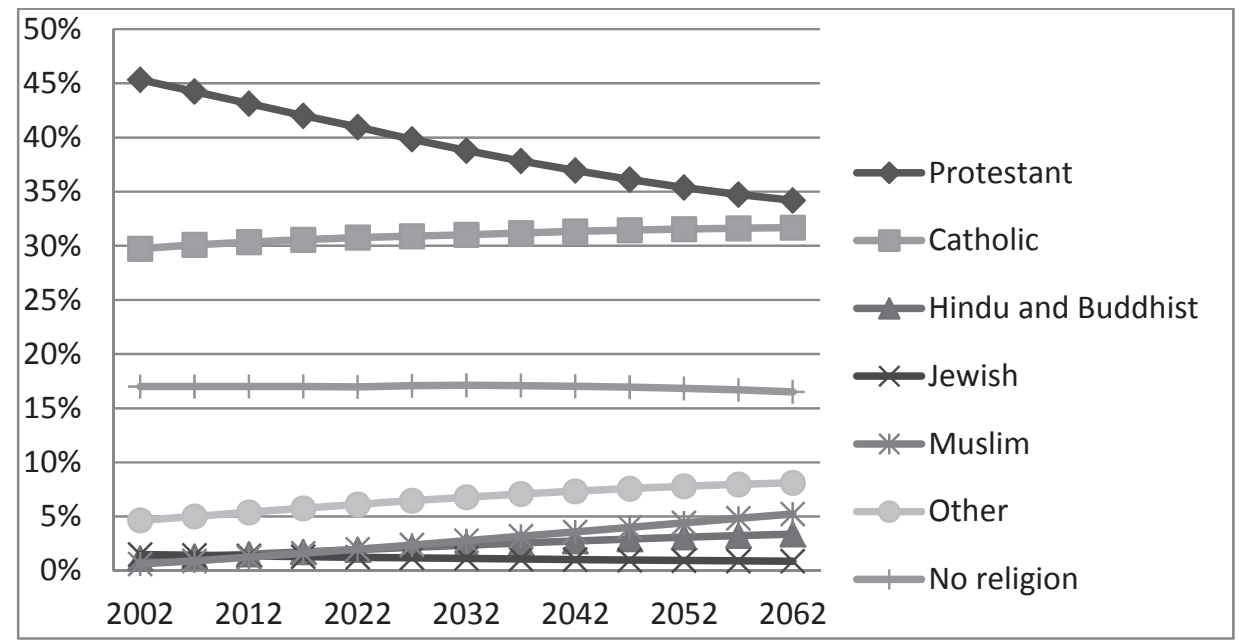

Source: Authors' calculations

\footnotetext{
${ }^{12}$ Since projections are carried out for the period 2001-2061 for Canada, and 2003-2063 for the US, we assumed that the results for North America are for the period 2002-2062, as an average of the two periods.
} 
The first half of the $21^{\text {st }}$ century would see a rapid increase of some religious minorities such as the Muslims - from $0.6 \%$ in 2002 to $5 \%$ in 2062 - and the Hindu Buddhists - from 1.2 percent in 2002 to 3 percent in 2062 - due mostly to positive net-migration and to the relative higher level of fertility of Muslims in both countries and also of Hindus and Buddhists in Canada.

The share of the secular group would slightly increase until 2012 to $17 \%$ and then decline slightly to $16.5 \%$ in 2062 , victim of a disadvantageous representation in the migration in the US and moreover of the low fertility of that group that is actually causing his importance to decline over time as was shown by Skirbekk et al in 2010 for the United States only, in spite of important transition from the dominant religion to that group - the secularization trend.

If we compare the different forces at play in the projections, we can see that future assumptions of migration and religious mobility (Figure 7, Figure 8 and Figure 9) have a larger bearing on the future North American religious landscape compared to fertility. However the relative importance of these forces is different if we compare the Protestants whose share is more sensitive to migration, with the Catholics whose representation would be more influenced by changes in the intensity of the religious mobility. In the case of a zero-netmigration from 2012 onwards, the share of the protestant population would stabilize at $42 \%$ of the total population throughout the projection period (from $45 \%$ in 2002) while this would mean a constant share of the Catholic population at 30\%. If migration doubles from 2012 onwards, then the proportion of Protestants would go down to $30 \%$ and that of the Catholics would increase slightly to $33 \%$. It is worth noting that the absence of religious mobility from 2012 onwards would have the same effect as a doubling of migration for the share of the Protestant population, but even more it would mean for the Catholics a substantial increase to $38 \%$ of the population where it would become the religion with the highest membership in North America. Surprisingly a late or early convergence of all fertility to the same level for women belonging to different religious denominations would not affect the share of the Protestant group in the total population - and that of the Catholics group very slightly - and this is due to the fact that those two groups have in fact very similar fertility in both countries and the realignment would not have such a substantial effect for the two dominant religious group as it would for the other denominations as we will see later.

Switching the net-migration religious composition of Canada and the US does not have an important effect on the share of the religious denominations, implying that those shares are very close, which is a comforting result that in the absence of data on the religion of the migrants, it actually makes overall sense to use the religious proportion of the country of birth of those migrants, and this is as well the case for minorities that are otherwise very sensitive to migration as can be seen from Figure 10, Figure 12 and Figure 13. On the other hand, the two countries are having different experiences in terms of religious mobility and the Protestants would lose tremendously if North America was to adopt the religious mobility of Canada and its share would be down to $26 \%$ in 2062 (compared to $34 \%$ in the recent situation scenario from $45 \%$ in 2002) and the Catholics up to $37 \%$ (compared to $32 \%$ in the recent situation scenario - from $30 \%$ in 2002). 
It is interesting to see that the population with no religion is not very sensitive to all of the scenarios and that its share stays more or less constant through all the years (Figure 14). Most interestingly and significant, it is the early fertility convergence scenario rather than any other scenario on religious mobility that would lead to the highest share of the population with no religion to $18.5 \%$ in the total population, which means that this group is really victim of its fertility behavior since it has very low fertility levels in both countries, way below replacement level.

Another religious denomination that would have a reduced share in the total population is the Jewish community (Figure 11) that surely would be overtaken by the Muslim population from 2017 onwards. The share of the Muslim population would range between 2 and $7 \%$ of the total population in 2062 depending on the scenario whereas around 1\% would be Jewish. The projections show that the Canadian immigration is less Muslim intensive than the American one and that American Muslims tend to lose more than Canadian Muslims through religious mobility. As expected, more than fertility, migration is one of the main engines of Muslim growth in Northern America which would not reach 2\% of the total population by 2062 in the absence of migration, but would reach more than $7 \%$ in the case of a doubling of migration.

In 2062, the third religious group in North America after the Protestants and the Catholics would be a group of other religions whose share could increase to $10 \%$ in the case of a Canadian religious mobility confirming this trend that Canadians and also U.S. citizens are moving away from traditional religions (Protestantism and Roman Catholicism) to other alternative religious denominations e.g. the evangelical Christians. Actually the scenario of no religious mobility would have the same effect as the business as usual scenario (recent situation).

The scenario implementing an intensification of mixed unions is not influencing greatly the share of the different religious groups. At most the difference between the recent situation and the mixed unions scenario is 1.5 percentage point and this in the case of the category without religion.

The changes in the religious shares of the total population can actually affect the generations differently since most changes occur at younger ages, either through religious mobility e.g. secularization or immigration. We have reported in Appendix Table 1 the shares by religion in North America according to three large age groups: $0-14,15-64$, and $65+$. It is interesting to see that the difference of religions between the young and the old generations is for most denominations larger in the starting year than it would be at the end of the projection period in most scenarios. The religious differences between generations were especially visible in 2002 for the Protestants whose share was $60 \%$ among the $65+$ age group compared to $38 \%$ among the 0-14 age group. Conversely, the same is true about those without religion who represented $22 \%$ of the $0-14$ age group and only $8 \%$ of the $65+$ in 2002 . For those two groups, the difference would level off by 2062: it would be less than 5 percentage-points in all scenarios for the Protestants; the largest gap occurring in the absence of migration where the share of Protestants would be increasing again, affecting first the younger generations. The effect of 
the low fertility and low presence in the immigration of the no religion category would entail that in 2062, the $0-14$ population would be in all scenarios more likely to belong to a religious group than the elderly population above 65 years of age, especially in the absence of religious mobility - an extreme scenario - but also in the business as usual scenario, even if to a lesser extent.

Figure 7. Share of the Catholic and Protestant population in the total population, North America, 2002-2062, several net-migration scenarios

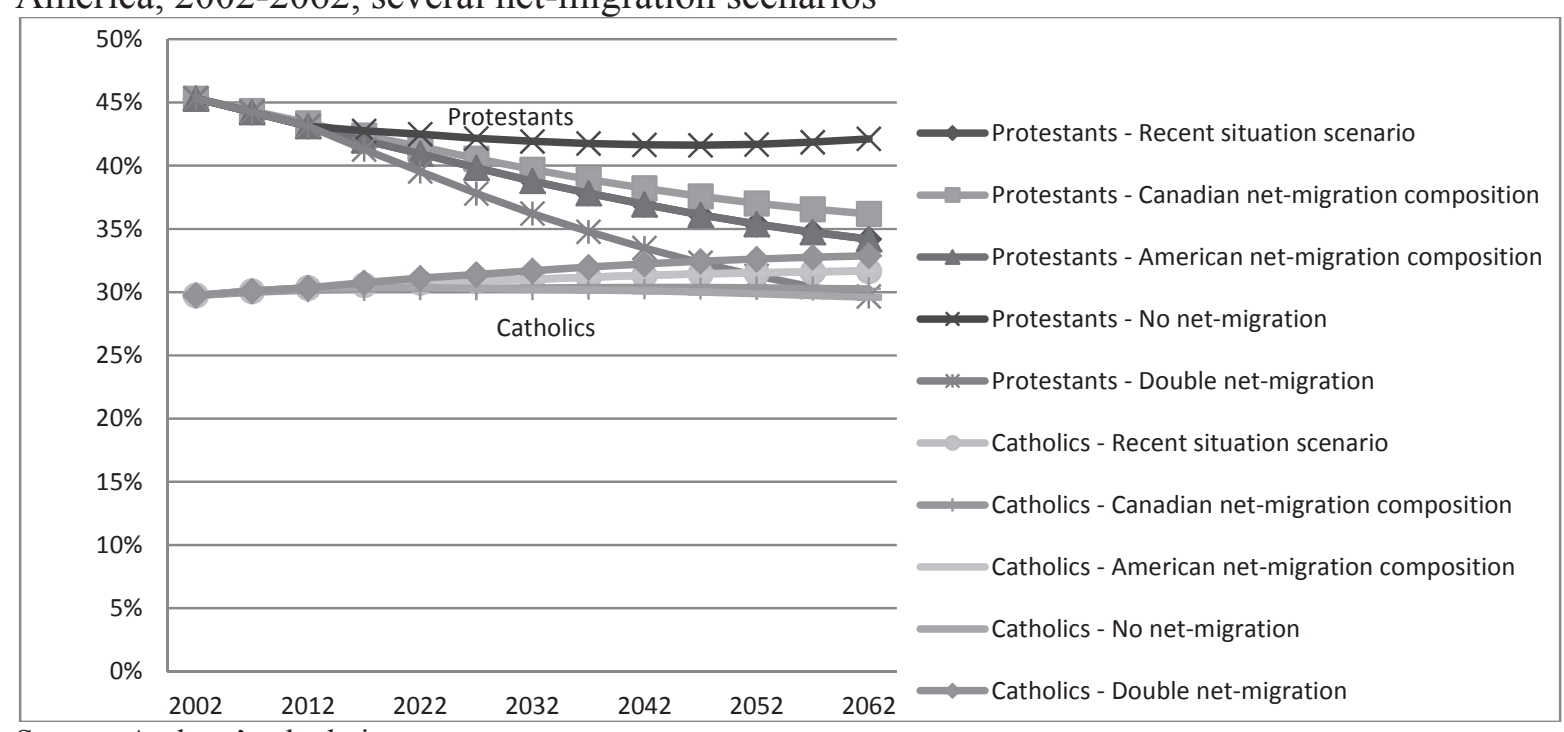

Source: Authors' calculations

Figure 8. Share of the Catholic and Protestant population in the total population, North America, 2002-2062, several religious mobility scenarios



Source: Authors' calculations 
Figure 9. Share of the Catholic and Protestant population in the total population, North America, 2002-2062, several fertility scenarios

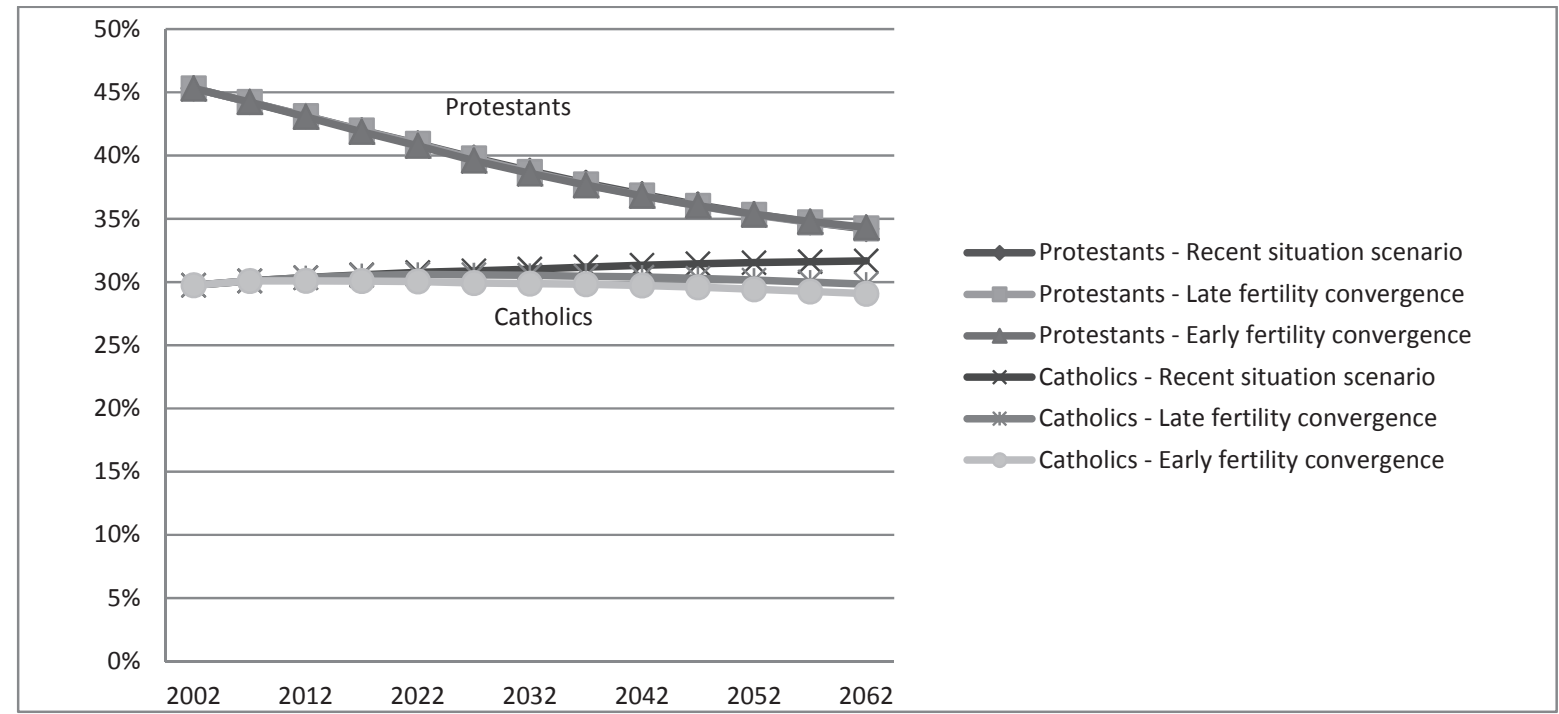

Source: Authors' calculations

Figure 10. Share of the Hindu-Buddhist population in the total population, North America, 2002-2062, 11 scenarios

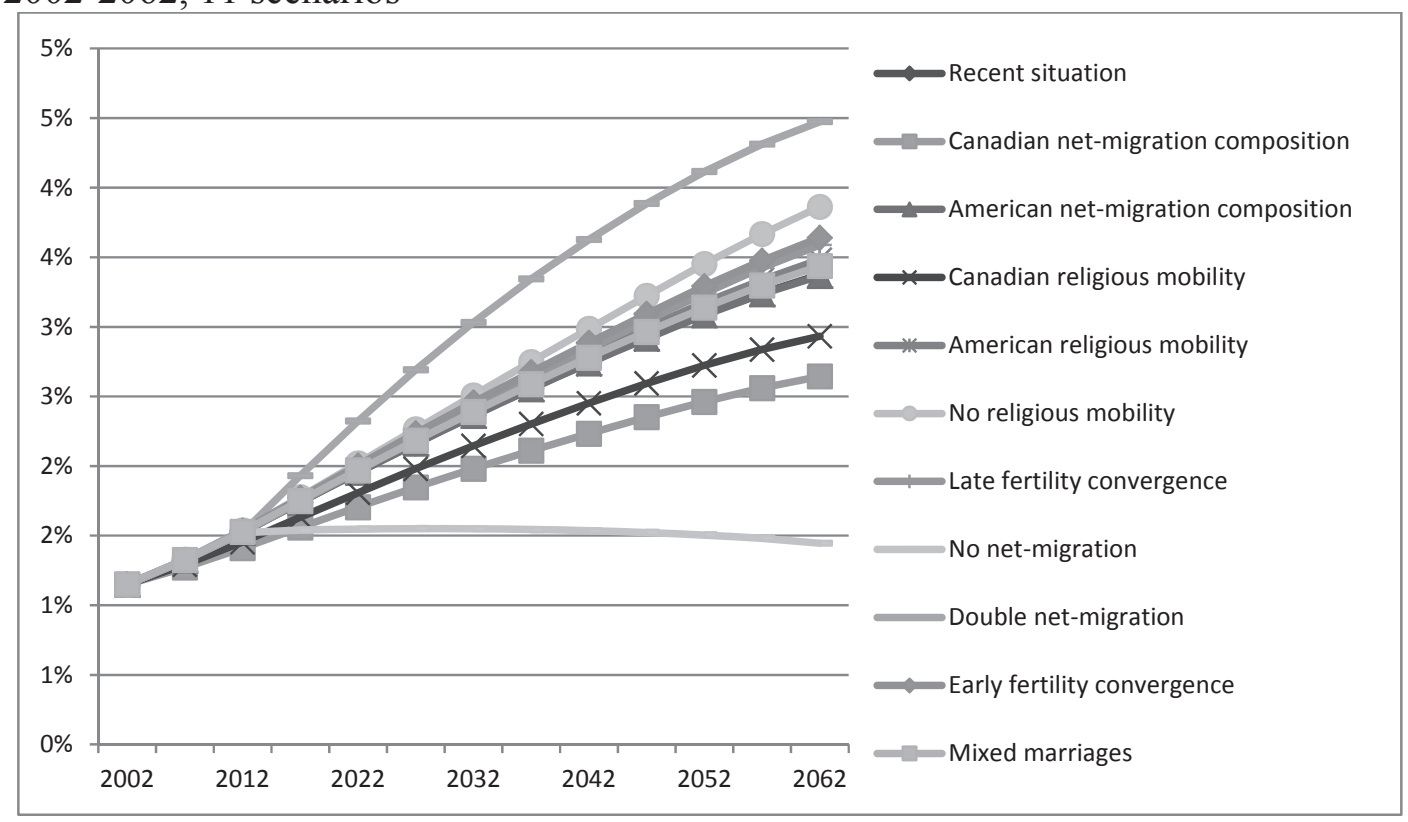

Source: Authors' calculations 
Figure 11. Share of the Jewish population in the total population, North America, 2002-2062, 11 scenarios

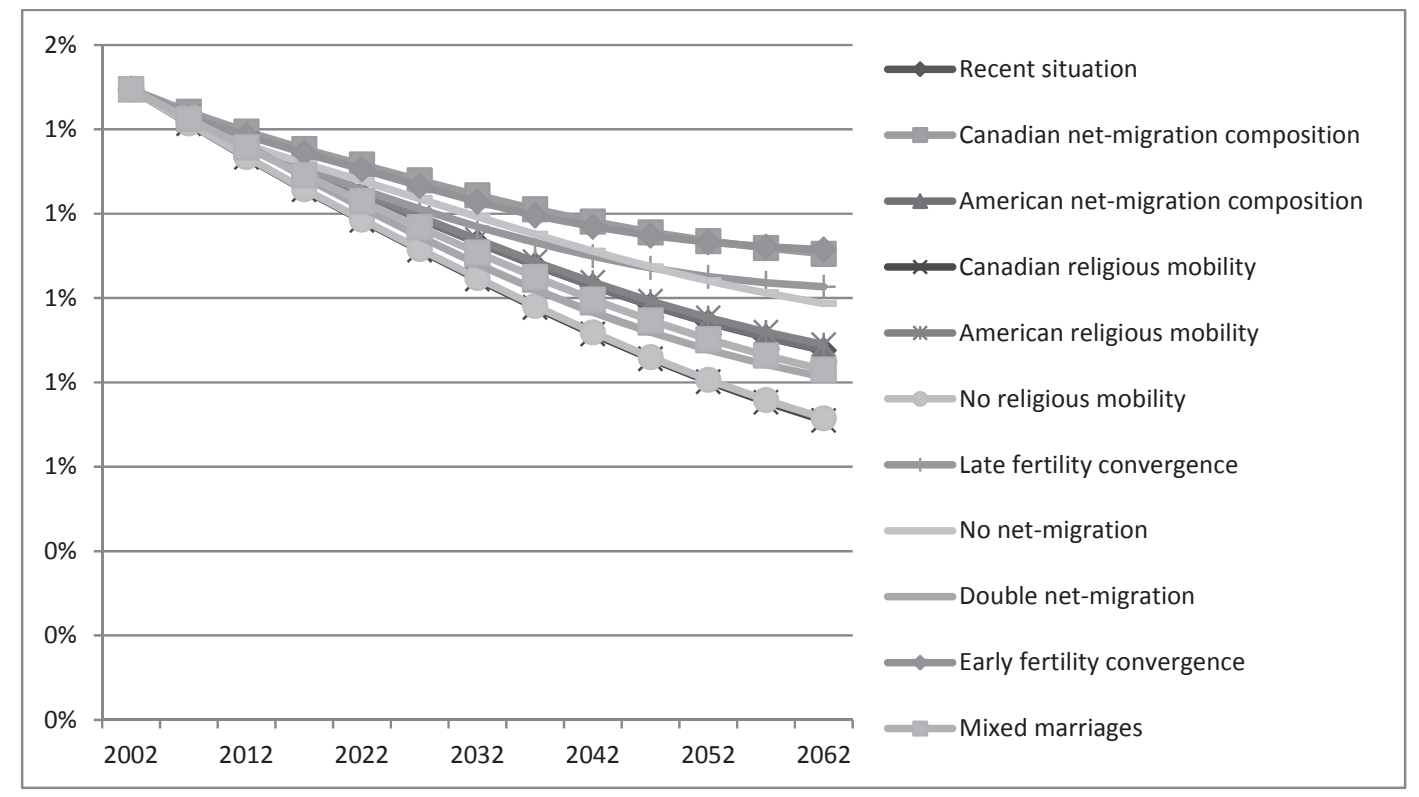

Source: Authors' calculations

Figure 12. Share of the Muslim population in the total population, North America, 2002-2062, 11 scenarios

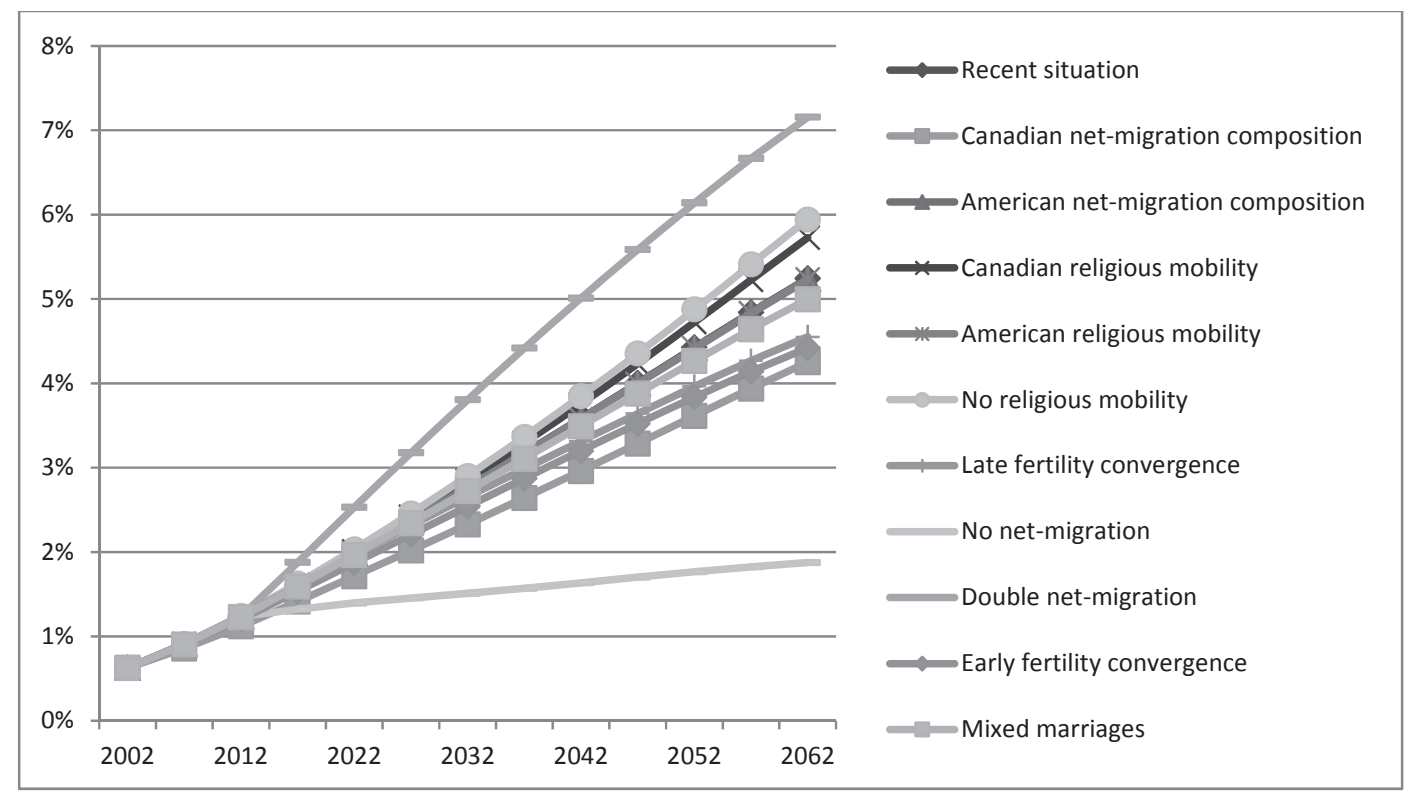

Source: Authors' calculations 
Figure 13. Share of the population with other religions in the total population, North America, 2002-2062, 11 scenarios

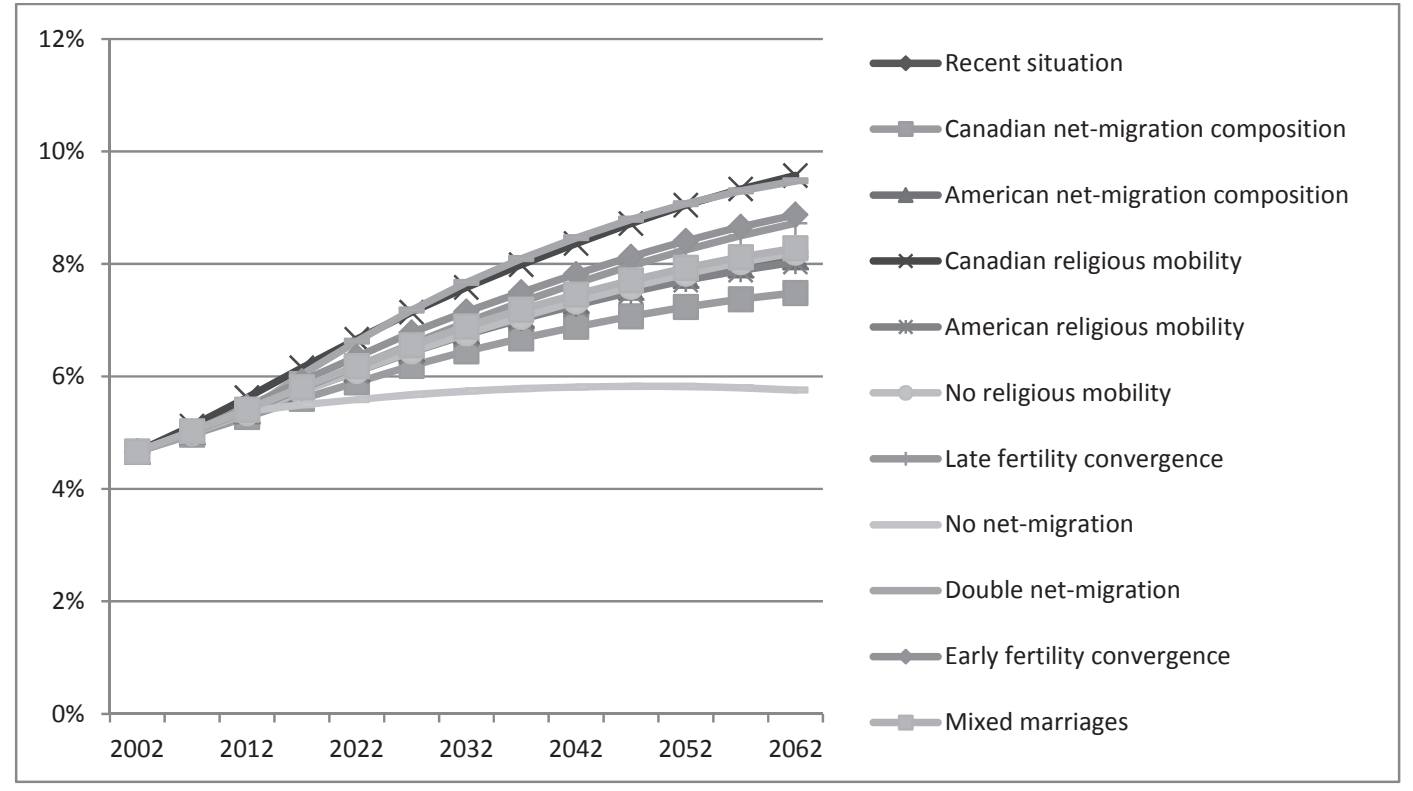

Source: Authors' calculations

Figure 14. Share of the population with no religion in the total population, North America, 2002-2062, 11 scenarios

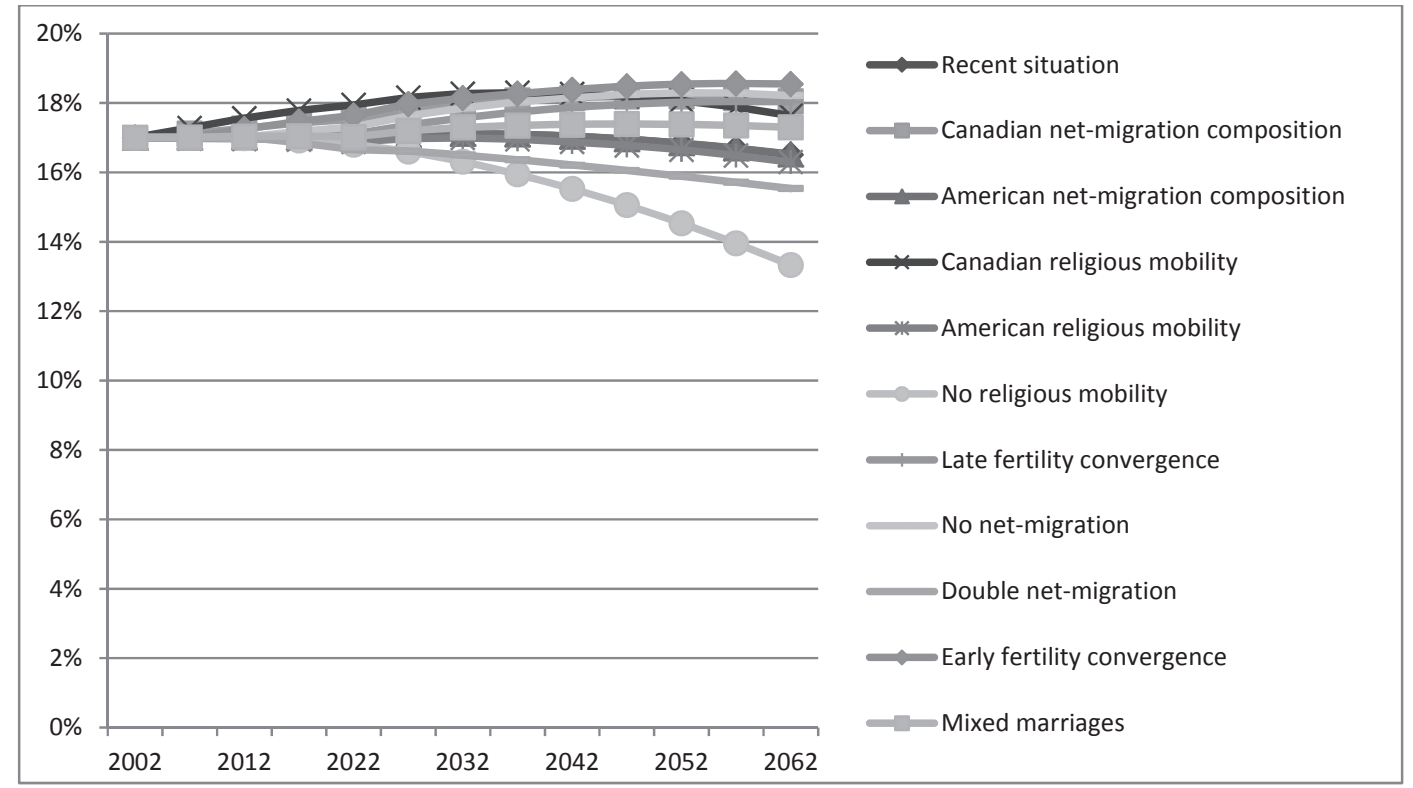

Source: Authors' calculations 
Since Canada disappears behind the US in the projection results for North America because of differences in population size, this section is dedicated to specific results of the projections for Canada. According to the recent situation scenario (Figure 15) both the Protestant and the Catholic denominations would be decreasing by more than 15 percentage points between 2001 and 2061, and the no religion group would increase its share to become the second group, after the Catholics, with more than $20 \%$ of the total population in 2061 . Canada would thus be very different in terms of religious composition than what it was one century ago, when the country was predominantly Protestant and when more than $90 \%$ of Canadians were either Protestants or Catholics. This change in the religious landscape of Canada would be due mostly - but not only -to religious mobility as well as immigration in which both Catholics and Protestants are underrepresented and almost all other groups (including no religion) overrepresented. Indeed, the only scenarios in which Protestants maintain an advantage on the no religion group by 2061 are those alternating different religious mobility and immigration paths: American religious mobility, No religious mobility and No migration (data not shown) ${ }^{13}$. But even according to these scenarios, the trends for the Protestant, Catholic and the no religion groups would remain in the same direction.

Figure 15. Share by religious category, Canada, Scenario 'Recent situation', 2001-2061

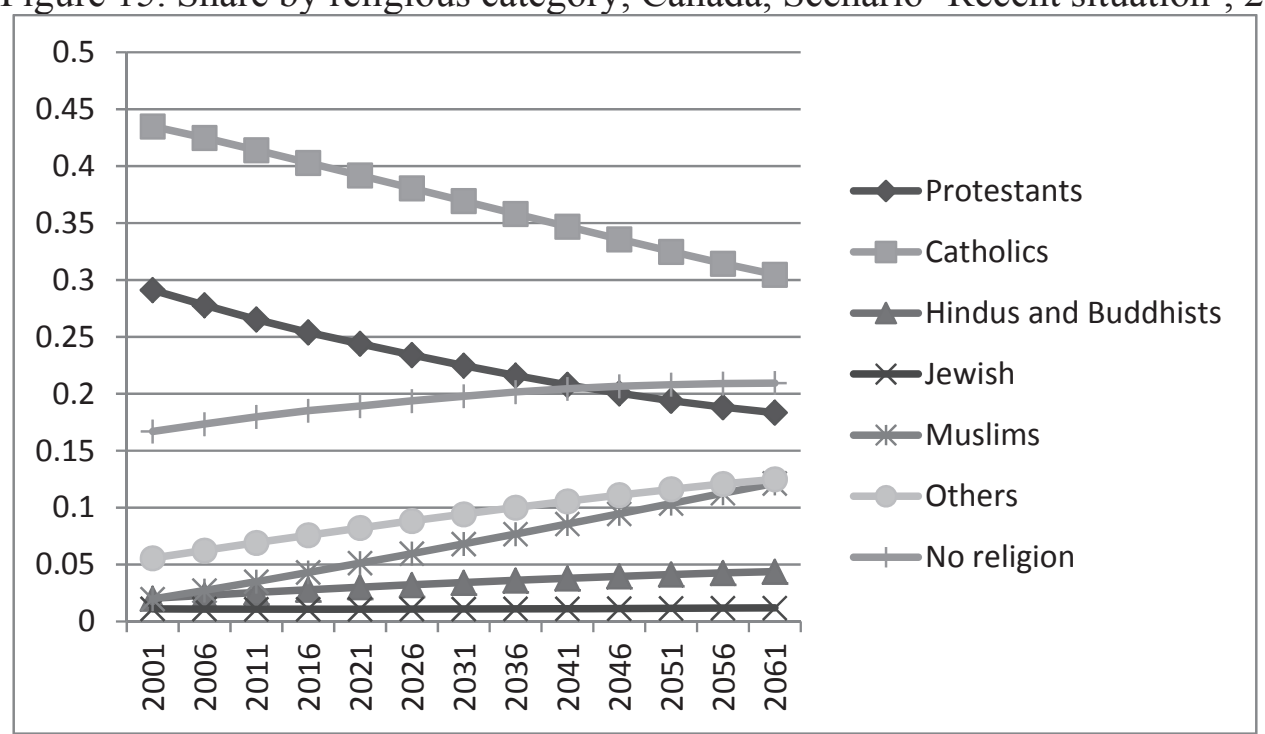

Source: Authors' calculations

The US and Canada are overall on a different path of religious diversification: whereas in the US, religious denominations would be still dominated by the Catholics and Protestants, Canada would see the share of those with other religions (Muslims, Hindus and Buddhists, and others) triple according to most scenarios until the $2060 \mathrm{~s}$, from around $10 \%$ to around $30 \%$, while the same share would increase from $6 \%$ to $15 \%$ in the US, in almost all scenarios. In

\footnotetext{
${ }^{13}$ Another factor is that Protestants and, to a lesser extent Catholics, are also older on average than the other groups (Statistics Canada 2003) which will lead to a high number of deaths when the baby boomers will reach old ages, in the first half of the $21^{\text {st }}$ century.
} 
most scenarios, the share of Hindu-Buddhists would reach between $4 \%$ and $6 \%$, while that of Muslim would reach between $10 \%$ and $13 \%$ in Canada by 2061 . Very sensitive to international migrations, these shares could be higher or lower if immigration were to increase or decrease significantly. This is especially true for the Muslim group, whose share in the Canadian population could be $6 \%$ without immigration but $15 \%$ if immigration doubles.

The results obtained for Canada can be compared, for validation purposes, to those prepared by Statistics Canada (Caron Malenfant et al. 2010) at mid-projection term, in 2031, the assumptions of the recent situation scenario being overall very close to that used for the reference scenario of the national statistical agency. Even if the two data series differ in their methods and in the fact that, as opposed to that of Statistics Canada, the current projections exclude the institutional population and do not assume any increase in the non permanent resident population, they are very consistent with regards to the projected religious composition of the Canadian population. As can be seen in Figure 16, both project a Catholic population that would represent about $36 \%$ of the Canadian population in 2031 , and shares of Protestants and no religion that would be very close each other with about $20 \%$. They are also consistent with regards to the other religious groups, with almost identical proportions of Muslims (7\%), of Hindus and Buddhists (between 3 and 4\%), persons of Jewish denomination $(1 \%)$ and other religions $(10 \%)$.

Figure 16. Comparison of the projected population by religious denomination in Canada in 2031, Authors' calculations (recent situation) and Statistics Canada (reference scenario in Caron Malenfant et al. 2010)

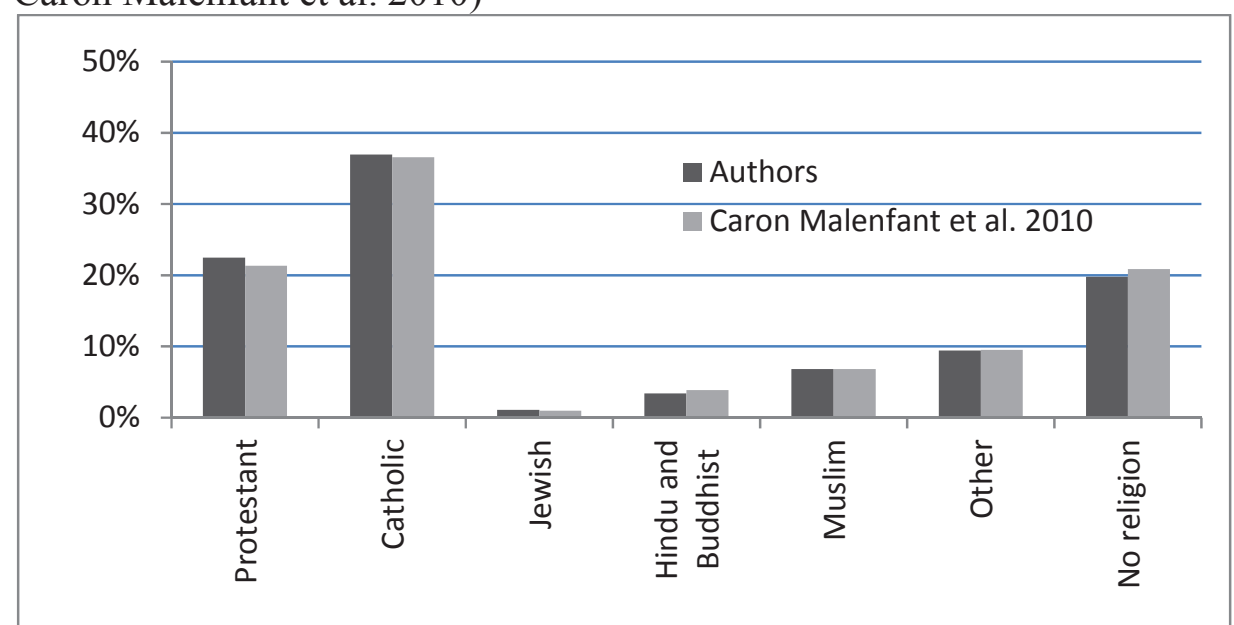

Source : Authors' calculations and Caron Malenfant et al. (2010)

\section{Conclusion and Discussion}

What could be the religious landscape of North America in 50 years from now? Is North America likely to become predominantly Catholic within the century as it happened to Canada 
between the 1961 and 1971 censuses? Our projections of the religious composition of Canada and the United States reveal, that for most combinations of hypotheses regarding future changes of fertility differentials, conversion and secularization rates, and migration, Catholicism would not be the main religious group in North America by mid $21^{\text {st }}$ century, but would be close to it as shown in Figure 17. Both Canada and the US would continue to be dominated by Christians, but the relative weight of the Protestants and Catholics is likely to change and religious minorities would grow in size. For all scenarios in Canada, we find that Catholicism is likely to keep its dominant position well into the second half of the $21^{\text {st }}$ century. However, although it is likely to remain the largest religion, its share of the population is likely to decline over the coming decades, particularly if immigration remains high and secularization continues.

Figure 17. Difference in 2062 between the shares of Protestants and Catholics (in \% points)

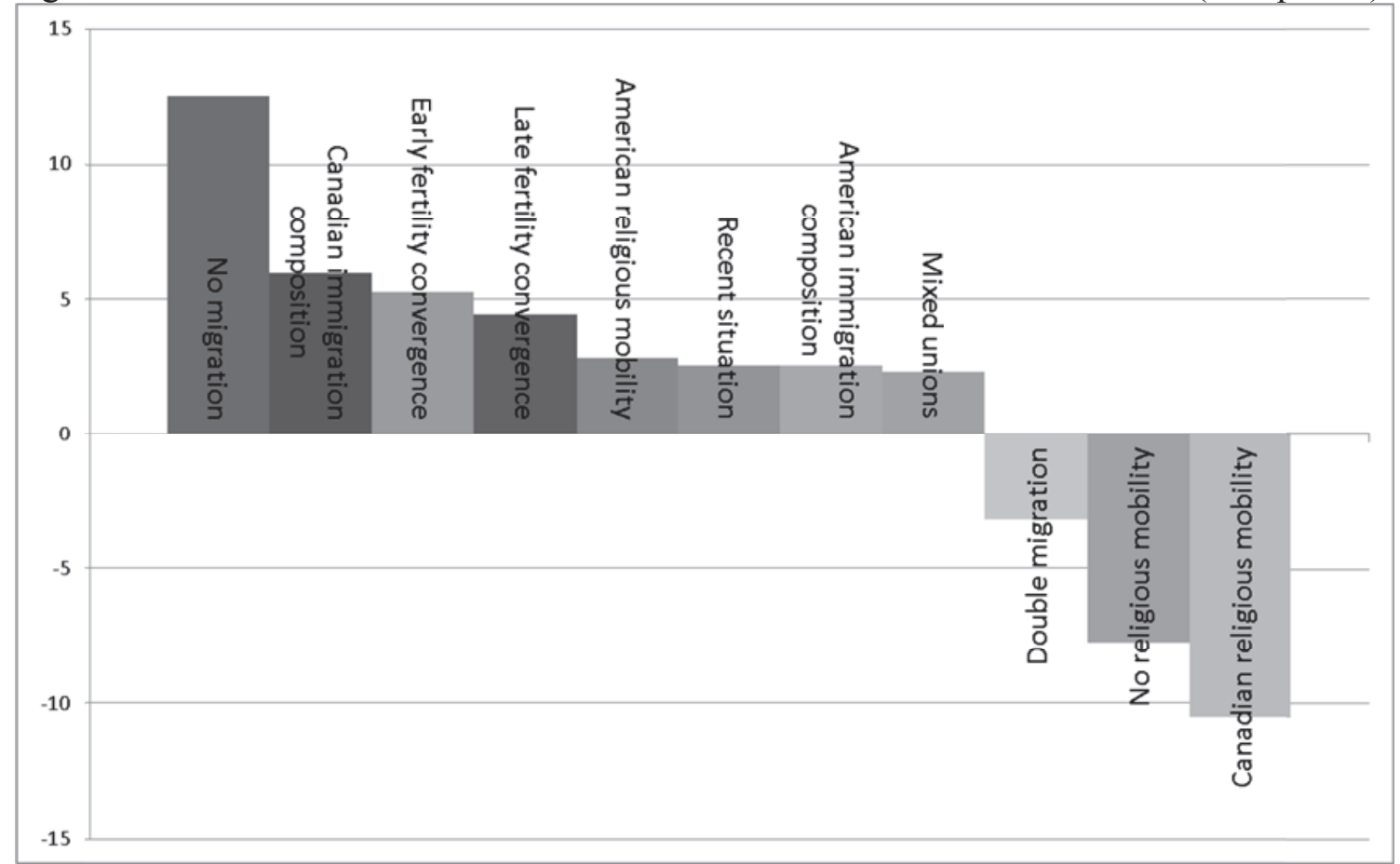

Source: Authors' calculations

It is important to mention that we only measure self-declared denomination, not the implication of having a given religious denomination, or the substantial differences in religious content and practice of each religion in the two countries. Religious affiliation could for some be a matter of self-identification with a cultural group, which could be the case among many French Canadians or Hispanic Catholic Americans. Formal affiliation does not necessarily imply that individuals will follow religious recommendations in terms of fertility, for instance the policies of the pope or leaders within various religious. We do not know whether adherence to a certain religion is likely to reflect a conservative political view or 
attitude. We also do not consider the large differences in fertility within religions (e.g. Protestant fundamentalists have higher fertility than liberal Protestants, Orthodox Jews have more children than moderate Jews), which also will affect fertility levels and conversion trends in future decades.

The content of Catholicism differs greatly between the two nations, and while US Catholic growth is driven by Mexican migration, Mexican migration is not significant in Canada. Our range of scenarios stresses that the religious switch is driven by demographic components and policies affecting these - if there should be strong reductions in migration to the US, there would be a lower share of Catholics in North America by 2060.

Unless there should be a rapid shift in conversion, migration or fertility levels, there would be a growth in minority religions (Islam, Hinduism and Buddhism, Other Religions) which results from continued immigration, a younger age structure, higher fertility and low losses through secularization and conversion to other religions. The Jewish share may decline in the US (due to low fertility, low immigration, and high secularization rates) but remain stable in Canada (due to continued immigration and relatively higher fertility). The population without religious affiliation is young, and is favoured by religious mobility, but low shares of non affiliated persons to the US as well as low childbearing levels in both Canada and the US are likely to stall the growth in secularization in the coming decades. 


\section{References}

Bélanger, Alain and Stéphane Gilbert. 2003. "The Fertility of Immigrant Women and their Canadian-Born Daughters," Report on the Demographic Situation in Canada, 2002, Statistics Canada Cat. 91-209.Ottawa: Statistics Canada.

Bélanger, Alain and Éric Caron Malenfant. 2005. Population projections of visible minority groups, Canada, provinces and regions: 2001-2017, Statistics Canada Cat. 91-541XIE.Ottawa: Statistics Canada

Bibby, Reginald W. 2002. Restless Gods - The renaissance of religion in Canada. Toronto: Stoddart Publishing Company Ltd.

Bisin, Alberto, Giorgio Topa, and Thierry Verdier. 2004. "Religious Intermarriage and Socialisation in the United States," Journal of Political Economy 112 (3): 615-664.

Bovay, Claude and Raphael Broquet. 2004. Le paysage religieux en Suisse. Recensement fédéral de la population 2000. Neuchâtel : Office fédéral de la statistique.

Boyle Torrey, Barbara and Nicholas Eberstadt. 2007. "The northern American fertility divide," in Roderic P. Beaujot and Don Kerr (eds.), The Changing Face of Canada: Essential Readings in Population. Toronto: Canadian Scholars' Press, pp. 43-58.

Boyle Torrey, Barbara. 2008. "Population Tectonics: Births, Deaths, and Immigration in North America," in David. M. Thomas and Barbara Boyle Torrey (eds.), Canada and the United States: Differences that Count, 3rd ed. Peterborough: Broadview Press, pp. 87-106.

Caron Malenfant, Éric and Alain Bélanger. 2006. "The Fertility of Visible Minority Women in Canada," Report on the Demographic Situation in Canada, 2003 and 2004, Statistics Canada Cat. 91-209. Ottawa: Statistics Canada.

Caron Malenfant, Éric., André Lebel, and Laurent Martel. 2010. "Projections of the Diversity of the Canadian Population," Statistics Canada Cat. 91-551-XWE. Ottawa: Statistics Canada.

Castells, Manuel. 2004. The Power of Identity. The Information Age: Economy, Society and Culture, Vol. II. Chichester, West Sussex: John Wiley and Sons Ltd,.

Clark, Warren. 2008. "Interreligious unions in Canada," Canadian Social Trends 11-008. Ottawa: Statistics Canada.

Crockett, Alasdair and David Voas. 2006. "Generations of decline: religious change in Twentieth-century Britain," Journal for the Scientific Study of Religion 45: 567-584.

Glaeser, Edward L. and Bruce I. Sacerdote. 2008. "Education and religion," Journal of Human Capital 2(2):188-215.

Goujon, Anne, Vegard Skirbekk, Katrin Fliegenschnee, and Pawel Strzelecki. 2007a. "New Times, Old Beliefs: Projecting the Future Size of Religions in Austria," 2007 Vienna Yearbook of Population Research: 237-270. 
Goujon, Anne, Vegard Skirbekk, and Katrin Fliegenschnee. 2007b. "New times, old beliefs: Investigating the future of religions in Austria and Switzerland," Work session on demographic projections, proceedings-Bucharest, 10-12 October, Eurostat Methodologies and working papers, 355-370.

Grabill, Wilson H., and Lee-Jai Cho. 1965. "Methodology for the Measurement of Current Fertility from Population Data on Young Children," Demography 2:50-73.

Groot, Wim and Henriette Maassen Van DenBrink. 2007. "The health effects of education," Economics of Education Review 26(2):186-200.

Guibernau Montserrat. 2007. The identity of nations. Cambridge: Polity Press.

Hoge, Dean R. 1981. Converts, Dropouts, and Returnees. New York: The Pilgrim Press.

Hollmann, Frederick W., Tammany J. Mulder, and Jeffrey E. Kallan. 2000. "Methodology and Assumptions for the Population Projections of the United States: 1999 to 2100," Population Division Working Paper No. 38. Washington, D.C.: Population Projections Branch, Population Division, U.S. Census Bureau.

Hummer, Robert A., Christopher G. Ellison, Richard G. Rogers, Benjamin E. Moulton, and Ron R. Romero. 2004. "Religious Involvement and Adult Mortality in the United States: Review and Perspective," Southern Medical Journal 97(12): 1223-1230.

Iannaccone, Laurence R. 1992. "Religious Practice: A Human Capital Approach," Journal for the Scientific Study of Religion 29: 297-314.

Inglehart, Ronald and Wayne E. Baker. 2000. "Modernization, cultural change, and the persistence of traditional values," American Sociological Review 65(1): 19-51.

Jasso, Guillermina and Mark R. Rosenzweig. 2006. "Characteristics of immigrants to the United States: 1820-2003," in Reed Ueda (ed.), Companion to American immigration.

Malden, MA: Blackwell Publishing, pp. 328-58.

Jones, Elise F. and Charles F. Westoff. 1979. "The end of Catholic fertility," Demography 16(2):209-18.

Kalmijn, Matthijs and Frank van Tubergen. 2010. “A comparative perspective on intermarriage: Explaining differences among national-origin groups in the United States," Demography 47(2): 459-479.

Krotki, Karol and Evelyn Lapierre. 1968."La Fecondité au Canada selon la Religion, l'Origine Ethnique, et L'Etat Matrimonial,“ Population 23: 815-834.

Kung, Hsiang-Ching, Donna L. Hoyert, Jiaquan Xu, and Sherry L. Murphy. 2008. "Deaths: Final data for 2005," National vital statistics reports, vol. 56, No. 10. Hyattsville, MD: National Center for Health Statistics.

Lehrer, Evelyn. 1996. "Religion as a determinant of fertility," Journal of Population Economics 9(2):173-96. 
Lehrer, Evelyn. 2004. "Religion as a determinant of economic and demographic behavior in the United States," Population and Development Review 30(4):707-726.

Lerch, Mathias, Michel Oris, Philippe Wanner, Yannic Forney, and Catriona Dutreuilh. 2010. "Religious Affiliation and Mortality in Switzerland, 1991-2004," Population (English edition) 65(2): 217-250.

McQuillan, Kevin. 2004. "When does religion influence fertility?" Population and Development Review 30(1):25-56.

Passel, Jeffrey S. 2006. The Size and Characteristics of the Unauthorized Migrant Population in the U.S. Estimates Based on the March 2005 Current Population Survey. Washington DC: Pew Hispanic Centre.

Sander, William. 1992. "Catholicism and the Economics of Fertility," Population Studies 46(3): 477-489.

Sherkat, Darren.2004."Religious Assortative Marriage in the Late 20th Century: Trends and Cohort Differences, 1973-1998,” Social Science Research 33:606-626.

Skirbekk, Vegard, Anne Goujon, and Eric Kaufmann. 2010. "Secularism, Fundamentalism, or Catholicism? The Religious Composition of the United States to 2043,"Journal for the Scientific Study of Religion 49(2):293-310.

Statistics Canada. 1993. "Religion," The Daily, Statistics Canada's official release bulletin, Statistics Canada Cat. 96-304E. Ottawa: Statistics Canada.

Statistics Canada. 2010. Population Projections for Canada, Provinces and Territories, 2009 to 2036, Statistics Canada Cat. 91-52. Ottawa: Statistics Canada.

Statistics Canada. 2003. Religions in Canada, 2001 Census: analysis series, Statistics Canada Cat. 96F0030. Ottawa: Statistics Canada.

U.S. Department of Homeland Security. 2009. Yearbook of immigration statistics, 2006.

Washington, DC: Government Printing Office. 







\section{VIENNA INSTITUTE OF DEMOGRAPHY}

\section{Working Papers}

Di Giulio, Paola, Christoph Bühler, Andreas Ette, Romina Fraboni, and Kerstin Ruckdeschel, Social Capital and Fertility Intentions: The Case of Italy, Bulgaria, and West Germany, VID Working Paper 02/2012.

Abel, Guy J., Estimating Global Migration Flow Tables Using Place of Birth Data, VID Working Paper 01/2012.

Ediev, Dalkhat M., At Modal Age at Death, the Hazard Rate is Determined by its Derivative, VID Working Paper 08/2011.

Zeman, Kryštof, Tomáš Sobotka, Richard Gisser, Maria Winkler-Dworak, and Wolfgang Lutz, Geburtenbarometer Vienna: Analysing Fertility Convergence between Vienna and Austria, VID Working Paper 07/2011 (English and German versions available).

Feichtinger Gustav, Michael Kuhn, Alexia Prskawetz, and Stefan Wrzaczek, The Reproductive Value as Part of the Shadow Price of Population, VID Working Paper 06/2011.

Barakat, Bilal, Time is Money: Could Deferred Graduate Retirement Finance Higher Education?, VID Working Paper 05/2011.

Riosmena, Fernando, Maria Winkler-Dworak, Alexia Prskawetz, and Gustav Feichtinger, The Impact of Policies Influencing the Demography of Age Structured Populations: Lessons from Academies of Science, VID Working Paper 04/2011.

Buber, Isabella and Katrin Fliegenschnee, Are you Ready for a Child? A Methodological Triangulation on Fertility Intentions in Austria, VID Working Paper $03 / 2011$

Fent, Thomas, Belinda Aparicio Diaz, and Alexia Prskawetz, Family Policies in the Context of Low Fertility and Social Structure, VID Working Paper 02/2011.

Buber, Isabella, Caroline Berghammer, and Alexia Prskawetz, Doing Science, Forgoing Childbearing? Evidence from a Sample of Female Scientists in Austria, VID Working Paper 01/2011.

Strulik, Holger, Klaus Prettner, and Alexia Prskawetz, R\&D-Based Growth in the Post-Modern Era, VID Working Paper 09/2010.

The Vienna Institute of Demography Working Paper Series receives only limited review. Views or opinions expressed herein are entirely those of the authors. 